\title{
RESEARCH PAPER \\ Transformative education in agroecology: student, teacher, and client involvement in colearning
}

\author{
Charles A. Francis ${ }^{1,2}$, Anna Marie Nicolaysen², Geir Lieblein², and Tor \\ Arvid Breland ${ }^{2}$
}

${ }^{1}$ University of Nebraska - Lincoln [UNL], Department of Agronomy and Horticulture. Lincoln, NE 685830915, U.S.A.

${ }^{2}$ Norwegian University of Life Science, Department of Plant Sciences. Posboks 5003, Aas, N-1432 Norway

\begin{abstract}
C.A. Francis, A.M. Nicolaysen, G. Lieblein, and T.A. Breland. (2020). Transformative education in agroecology: student, teacher, and client involvement in colearning. Int. J. Agric. Nat. Resour. 280-294. Educational methods have evolved rapidly in agroecology, which is a complex and holistic field without a long history or the formal tradition of any single academic discipline. Definitions of agroecology have evolved from its initial conception as a marriage of agriculture with ecology, to an aggregation of different paths including science, practices, and movements, and recently as a broad appreciation of the ecology of food systems. In contrast with traditional courses that begin with a history of the discipline and review the contributions of early leaders, we have embraced phenomenology to firmly establish roots in students' learning through their experiences interacting with farmers and practitioners in food systems. We have pursued close collaborations among students, teachers, farmers, processors, retailers, consumers, and government officials to build ownership of the learning process in a transdisciplinary education model. Working together in the learning landscape, we have codeveloped visions of sustainable systems for the future. As a team, we are searching for meaning and applications to help advance substantial changes in the production and consumption of food and more importantly, a transformation in thinking about educational alternatives. Our learning program's focus is catalyzing the student journey by developing five competencies: observation, dialogue, participation, reflection, and visioning. Implementing the program requires fundamental changes towards colearning involving students, instructors, and stakeholders, plus modifications in the institutional environment. With well-focused skills and practice, our graduates are prepared to deal with a complex and unpredictable future, where many of the questions and challenges are yet to be discovered. By involving students and others in design, this becomes a process of empowering each participant to take responsibility for their education and preparing them for lifelong learning with the motivation to be an active and responsible agent of change.
\end{abstract}

Keywords: Administrator involvement, colearning, phenomenology, stakeholder involvement, student involvement. 


\section{Introduction}

Practical and relevant education in farming and food systems becomes more urgent every day as the pressure to adopt high-input production methods and consolidate farmland into everlarger operations becomes the norm (MacDonald, Hoppe, \& Newton, 2018). In many agricultural universities, teaching emphasizes high-tech and ever more expensive technologies while moving away from approaches that follow ecological principles. Ecological system design includes incorporating biodiversity in fields and landscapes, niche specificity that tailors a crop and its management to unique soils and farm characteristics, promoting nutrient and water cycling on-farm, and crop/animal integration in agroecosystems (Wezel et al., 2014). When viewed through the lens of ecology, the negative emergent properties of industrial agriculture include changes towards larger fields and farms and the homogenization of practices and systems over extensive areas. Alternative approaches to this norm in farming, plus educational innovations to promote them that include close collaborations with stakeholders, have been developed and applied in our agroecology program in Norway (Lieblein, Breland, Francis, \& Østergaard, 2012). The importance of well-oriented and appropriately trained leaders in the workforce will be essential for a needed transformation in agriculture (Carlisle et al., 2019). Learning skills, gaining practice, and embracing colearning could inform a transformational strategy for students to learn through academic activities and prepare them for responsible action in future careers.

In a rapidly changing information environment, we embrace the obvious reality that a traditional professor who lectures on a topic as an authority is likely not the most current, comprehensive, nor authoritative expert in their field. Students with a cell phone in hand or laptop on their desk can Google $\odot$ or ask Siri $\odot$ for quick information on a near-infinite number of topics. We need to carve out new niches where experience and perspective plus examples from our own lives can help students sort out information and develop appropriate applications. Related to the philosophy of Freire (1968), this new strategy could be called a 'democratic approach' to the course design and the role of instructors (Kainer et al., 2019). The change from 'expert to colearning catalyst' may be a challenge for many. The self-image of teachers and their long experience may be potential barriers to effective and applied education in the new learning landscape. Students may also not be prepared to leave the comfort of a 'passive learning' role, and stakeholders may not be prepared for expanded responsibilities. The challenges and potential solutions for these issues are explored here.

One way to build motivation and introduce students to current challenges in farming and food systems is to follow the philosophy of learning through 'phenomenology,' starting their experiences in the 'real world' by working on farms, interviewing farmers, and learning directly from practitioners in the food system (Østergaard, Lieblein, Breland, \& Francis, 2010). This approach provides a shared context for class meetings where we introduce theory and additional information, with discussions often centering around recently shared experiences on farms and in communities. Although many teachers are not familiar with the term 'phenomenology' or its origins, this is already used in practice as we design field activities and bring information into the classroom through videos, farmer visits to class, and review of case studies. We argue that none of these is equivalent to the actual student experience in the field, where they walk through farms and use all their senses to absorb a farm landscape's reality and complexity. The roots of this approach are discussed in a later section and how similar educational strategies have been applied in the Nordic countries, France, India, Ethiopia, and Uganda.

To achieve specific goals in agroecology courses, we introduce the importance of five competen- 
cies - observation, participation, dialogue, reflection, and visioning — and provide a safe space for students to observe and practice each of them in the field, community, and classroom. In contrast to 'teaching agroecology,' we strive to help students along the path to 'becoming an agroecologist' through study and practical experience (Lieblein, Østergaard, \& Francis, 2004). Students with key competencies become course outputs, and we designed our evaluation using student learning documents and class activities that allow us to monitor the process and give continual feedback. These are described later in this article.

We provide an overview of the context of an agroecology MSc course at Norwegian University of Life Sciences (NMBU), including experiences with students, instructors, and stakeholders over the past twenty years of the program. The formal degree programs we helped initiate and then mentored in other universities all operate in specific institutional settings. Creating these programs required designing and managing new learning landscapes as part of each transformation process. The authors brought over 125 years of collective teaching experience from universities, in both the Global North and the Global South, and applied this knowledge in the present context of changes in the learning environment in the information age. We recognize that our experience is valuable in planning courses and the choice of activities. At the same time, it is important to acknowledge that others can provide valuable input in shaping the learning agenda. Colearning is one method of bringing in these additional insights and expertise.

Although we have traveled, worked, observed, and taught in several developing-world countries, there is an obvious bias based on our experiences in Nordic countries, where the relatively flat and shared societal governance is reflected (to some degree) in the universities. Students there are often encouraged to take an active role in learning. We also admit to a degree of ignorance about many participatory learning activities in agroecology movements, especially in Latin America. Most of the specific examples come from the Global North. Recent mentoring and support for new agroecology MSc and certificate programs in India, Ethiopia, and Uganda have broadened our appreciation of cultural and structural differences in education and have given us a learning opportunity to see how goals can be generalized and participatory learning methods adapted to other specific learning landscapes. This paper describes how we arrived at using participatory colearning in the program, and the challenges and opportunities we see for students, teachers, and clients in farming and food systems to implement the transformation process. We also provide a vision for how we anticipate that education will evolve in the future to help develop agroecologists who will become agents of change through responsible actions, and apply their competencies in greatly different circumstances.

\section{The Evolving Educational Landscape in the Agroecology MSc in Norway}

The foundation for our MSc program was developed in a series of three one-week $\mathrm{PhD}$ courses in the mid-1990s that generated a growing appreciation for broadening both the scope and scale of thinking about agroecology. The course titles were Integrated Farming Practices in 1995, Holistic and Integrated Farming Practices in 1996, and Farming and Food Systems in 1997. Their design led to an exploration of open-ended learning methods (Francis et al., 2009). In a series of visits to local biodynamic farms each year, student teams interviewed farmers, walked the fields, observed crop and livestock enterprises and integrated systems, and quizzed farmers about their visions regarding long-term goals for improving their farms and marketing opportunities. The goals of an 'open-ended' dialogue with the farmer and the later student discussions were not to arrive at specific recommendations as if they were agricultural advisors or consultants but to vision together and develop potential scenarios that farmers could use to help clarify their goals and then plan strategies meet them. This was an 
early approach to colearning, where students, instructors, and stakeholders worked together to help design a more desirable future. The courses were evaluated two years later by a group of participants from each course who reported that they used the course skills in future studies or when planning the design of new educational programs (Lieblein et al., 2000).

The philosophy continued to gain interest, and our perspectives broadened to embrace food systems. In 2000, ideas in agroecology were used to inform the design of a comprehensive two-year MSc degree program in Norway. Program learning activities are summarized in the book by Mendez, Bacon, Cohen, \& Gliessman (2015), Agroecology: a transdisciplinary, participatory, and action-oriented approach. Chapter 5 in this book, "Learning agroecology through involvement and reflection" (Francis et al., 2015), outlines the importance of students gaining perspective and practice while achieving five specific competencies of observation, dialogue, participation, reflection, and visioning. The overall learning goals in both the original doctoral short courses and the current MSc two-year curriculum continue as they were initially conceptualized [Ibid., p. 86], with students developing:

- An ability to handle complexity and change;

- An ability to link theory to real-life situations;

- Practical communication and facilitation skills; and

- A capacity for autonomous and lifelong learning.

The MSc autumn introductory course title, Agroecology: Farming and Food Systems [PAE302] at the NMBU, reflects our growing appreciation of how farming and marketing are intimately linked. We predict that farming will have to become more dependent on ecological principles and internal, locally renewable resources in the future. Local food systems, including urban and peri-urban food production, will continue to increase even in the face of current trends towards globalization. The potential fragility of a global food system in the face of the recent COVID-19 global pandemic provides one example of why we need systems thinking and the meaningful participation of multiple players in educational planning and implementation. These factors all shaped our thinking when designing courses and compelled us to involve students and stakeholders in the coeducation process.

Recent additions to the agroecology team's scope include the 12-country EU-funded Project NEXTFOOD that is designed to promote participatory learning and to share ideas among diverse learning programs. They include academic MSc study curricula, certificate programs, and outreach/ extension initiatives in Europe, Asia, and Africa. Our student teams are working with leaders in the school food system in Viken County, Norway, whose government recently adopted a resolution to increase the share of organic products used in the food served at its high school canteens to $25 \%$. Students are also involved in doing case work in the research projects 'Cultivating Public Spaces', where we explore how urban agriculture can improve the quality of life in compact cities and how it can be integrated into public spaces, and in Sustainable Adaptation - Resilience in Urban Regeneration (ADAPT), where we are focusing on urban regeneration and green transformation. These projects have given our students sites to practice dialogue and visioning with stakeholders in the field, allowing us to add three people to the agroecology research and education team at NMBU.

\section{Transforming Students into Full Participants in Colearning}

We think many of the challenges students face in accepting a role in the active codesign of the learning landscape may come from their years of 
prior experience as passive learners in hierarchical educational systems, mainly confined to classrooms and lectures. For students from many countries, there is still a strong sense that teachers are the authorities with the best information that needs to be learned (usually memorized) and later applied; practical applications are not often an explicit part of university program goals. There is variation in access to the internet, although this is improving. The university environment varies among different countries. Social divides have been apparent when students tell us during a potluck dinner or waffle breakfast in one of the faculty member's homes that "We have never been to the house of a teacher to share a meal. That is just not a part of our culture". As enrichment in the array of learning approaches grows, we see these shared activities as part of building trust and establishing an interactive educational community that can contribute to colearning at universities (Francis, Morse, Lieblein, \& Breland, 2011).

Another structural part of the course and curriculum is the use of reflection and student feedback as integral and continuing forms of evaluation, resulting in extensive information on each student's learning at numerous points from their first semester through two years of the MSc program. In contrast to a conventional course where one midterm exam and one comprehensive final may be the extent of evaluation, and where students put all their efforts into memorizing facts and equations to pass the test and achieve a good course grade, our process is comprehensive. At least once each week, there is a structured reflection on what has been learned, and we often finish each topic with a short time for feedback from students. Recognizing there is limited prior student experience with this new paradigm, we have found a need for open discussion about why reflection is important. Many are surprised to learn that reflection is perhaps the most underrated and underutilized form of education. Instructors describe how we will use the information to improve the immediate learning environment and modify the future course structure. Every two weeks, we have a written evaluation where students score each activity on a Likert scale from one to seven and provide written comments to explain each rating. The teaching team discusses the written evaluations and considers changes in learning strategies in response to student ideas. At the end of the semester, a learner reflection document is required, forming $30 \%$ of the final grade. These are individual requirements and give us a window on each student's opinions on how well they have met the course learning objectives.

In a final reflection session at the end of the autumn semester fifteen years ago, after all the assignments were completed, we sat in a circle sharing lunch and decided to go around the table for a final comment from each student and teacher. One student interrupted the session, saying "Please wait while I make a comment to start the process. You should all realize that this is the first time in nearly twenty years as a student that anyone has asked what I thought of a course". We wanted to rejoice in realizing that a safe space had been created where this type of participation was welcome and accepted. However, we felt like weeping for all the lost time and nonparticipation that this student had experienced in prior educational situations. This one student was not unique with playing such a passive role in prior years of formal education.

From these experiences, we recognize and anticipate the difficulties many students may have in accepting new roles as colearners, and the challenge we have as educational catalysts to establish the trust and transparency essential to learn what is truly going on. It is our continuing goal to create the 'immediacy' and trust with students that convinces them we truly care about their ideas and that for us, their learning is far more important than our teaching (Estepp \& Roberts, 2015).

Another example serves to illustrate the potential for student conversion. In 2003 in Estonia, initial plans were to have 37 hours of lecture and 3 hours of discussion as the structure for a one-week 
doctoral course in sustainable agriculture. After lengthy phone discussions, our coinstructors were convinced that we should change this strategy. A compromise resulted in restructuring to half of the time in lectures and the other half in guided discussions. For two hours on the first day of the course, we reinforced and validated active student roles by letting each student present their in-depth personal biography. Soon we realized that the English language was a barrier for the students from Russia, Poland, and other former SSRs in the region. In one session later in the week, we divided into two groups for a topic discussion; half the class was comfortable with English and half more fluent in Russian. The final course evaluations revealed that students were surprised and pleased with their roles as respected full participants and sources of experience during the week and that we adapted the learning venue to account for different language capabilities. Similar ongoing flexibility by instructors in managing the learning environment has improved communication and builds on the reality that people learn differently. When a course is only in English, there are subtle differences in meaning for people who do not speak this as their native language (Wezel \& Francis, 2014). Our student transformation observations are informed by frequent reflection sessions, the final individual learner reflection document, and conversations with students beginning in the fall semester and continuing through with all students while completing a thesis project.

\section{Instructors Transforming into New Roles as Co-Learners}

When students are participants following long traditions of passive listening, and teachers are lecturers who conduct a 'one-way communication' of theories and facts, everyone is in a familiar 'comfort zone' where roles are clear, and expectations are similar in every course. When placed in a new situation where learning goals may be clear, but the process suddenly becomes different, there can be discomfort on both sides. As instructors, we have been exposed to stimulating lectures in the past and may aspire to emulate those role model presentations. Visual communications have been enhanced by PowerPoint as well as interactive electronic programs used in the classroom. Nevertheless, we are reminded by visiting the learning pyramid that information retained from lectures is approximately $5 \%$, from reading $10 \%$, and from audio-visual materials $20 \%$, with combinations of these activities resulting in slightly higher retention values [Education Corner, n.d., available at https://www.educationcorner.com/]. As instructors, we use these methods because we are familiar with them, and the tools become better and more accessible all the time. However, we must pause to ask, "Are these teacher behaviors truly contributing to learning"? According to conventional wisdom, we may increasingly be 'doing things right' and even better than before, but are we 'doing the right things' to catalyze the learning process? We are convinced that it is better to learn useful skills and apply them than to have students complete a course that supposedly 'covers all the material'. This demonstrates a large difference between 'learning agroecology' and 'becoming an agroecologist' (Lieblein et al., 2004).

Evidence that this new competence as 'an agroecologist' leads to graduates' success comes from our observations of individual experiences during student thesis research and in their next positions, where they are using tools from the course. Several students reported using visioning sessions in focus groups with their stakeholders, catalyzing a process for groups that helped them put aside their current constraints and explore a desirable future. A student researching the impact of organic farming methods in Tanzania convened a two-day workshop at Morogoro (now Sekoine) Agricultural University, where 25 stakeholders developed an agenda to increase sustainable organic farming techniques to improve farmer incomes. A recent graduate used interactive workshops in Kenya to determine the value of demonstration farms and how to best design them. 
Success with innovative methods outside the classroom has been reported elsewhere. Hartemink et al. (2014) described success in 15 case studies from several countries teaching soil science. Students gained both 'inspiration and knowledge' in the field derived from creative methods designed by instructors. Field, Yates, Koppi, McBratney, and Jarratt (2017) described the importance of enlisting stakeholders in planning soil science courses, and how this improved the students' problem-solving skills by enhancing the value of the primary knowledge and integrated fieldwork included in the courses.

One frequent comment from instructors during workshops on learning methods is that there is no time to implement participatory methods. This is an extension of the argument that it is essential to cover all the material expected in a conventional course to resemble similar courses at other universities. Most of the us recognize that it also takes more time to prepare, master different logistics, and modify roles described above. One who is convinced of the value of participatory learning could answer that there is a fixed amount of time available in each course and that it is our choice as instructors how to invest that time to foster learning. Again, if we are more interested in student learning than in our teaching a certain amount of new material, we should opt for the enhanced learning alternative.

There are many ways to make the best use of time in class and in the field, such as prior reading or web search assignments to prepare well for class, and doing adequate background research before a field trip so that the time with a farmer can be spent dealing with higher-order questions, rather than how many hectares are planted in each crop, or in asking about the details of hybrids or row widths. The idea of a 'flipped classroom' is gaining popularity, where lectures and some exercises are covered with prepared materials available online and with incentives to ensure that everyone will arrive in class well prepared (Conroy, Overson, \& Erickson, 2019). Thus, students and instructors can spend valuable time together in discussion and hands-on activities. 'Service learning' is a concept pioneered by Jordan, Andow, \& Mercer (2005) to describe the integration of holistic and systems thinking into classes, followed by engaging stakeholders on farms and in communities to address their challenges cooperatively; the goal is to help students develop a capacity for 'civic professionalism' to deal with the complexities and uncertainties they will face in their future careers. Problem-based and team-based learning are additional terms used to describe student involvement with stakeholders in the field (McCubbins, Paulsen, \& Anderson, 2019), with activities that build student capacities to engage with people and their challenges, and to prepare them for engaged careers after graduation. These are among the many options being applied within the current university structure to focus on practical outcomes, including building student confidence to deal with real-world challenges. Can this transformation be achieved by broadening the planning agenda to include more of the players?

How willing are instructors to consider a change? In a survey conducted among organic agriculture and agroecology teachers in 2018, twelve teachers from the European Network of Organic Agriculture and Agroecology Teachers (ENOAT) indicated that the top five issues of importance for them for improving learning, with scores on a Likert scale from one to seven, were the following (Francis and Steiro, 2018):

Field trips and dialogue with stakeholders to help learning [6.97/7]

It is important to use participatory learning in my classes [6.47/7]

Working on farms and in food systems promote learning

I would like more training in participatory learning methods [6.00/7] 
It takes more time to plan participatory activities

In addition to these ratings, teachers' opinions indicated that students learn more during internships than in lectures [47\%]; that good lectures are the best way to help students [32\%]; and that teachers think students learn the most in lectures [32\%]. One-third of the teachers reported that they do not have a budget for learning outside the classroom. One or more teachers also mentioned they need:

- More time for teaching plus more tutors to support them

- To make teaching and learning more interesting

- To learn from students and from farmers about real production problems on farms

- Ways to improve the practical training of students

- To respect students as 'auxiliary scientists' and support them in projects through scholarships

- To eliminate one-way education and motivate teachers to change

- To take an active role in finding good learning activities, and create more compulsory excursions

Last, most teachers recognized their own need to learn and practice new teaching styles, and when possible to divide large classes into small groups to improve the learning environment. However, it was not clear how willing they were to make substantive changes in teaching methods.

Although some teachers expressed curiosity about methods and willingness to change, perhaps one of the most daunting challenges we face as instructors is our own change in self-image, from that of an expert on the stage who provides all the best information, to becoming a catalyst who guides the learning process, helping students use all available sources of ideas and information. As instructors, we each have unique prior experiences and much to offer, such as criteria to use in selecting and evaluating resources, interpreting data and recommendations in the context of whole systems and farmers' goals, and helping students gain perspectives on what impacts different enterprises and systems will have on food supply, nutrition, and general human well-being. If we continue playing the role of supposed purveyor of all useful information, students will recognize this illusion when they consider the near-infinite, comprehensive, and timely resources available on the internet. Students need help in sorting out the information they access, especially in applying what they learn in responsible ways, leading to greater equity in the food system. In this, our guidance as teachers can play a vital role.

\section{Transforming Stakeholders into Co-Learners}

One of the frustrations faced by advisors or extension specialists is answering the same questions year after year from farmers. Partly because of the complexity of farming and difficulty keeping up with new technologies (such as seed sources, fertilizers, agricultural chemicals), many farmers have become dependent on others as consultants, sources who are considered authorities and the best conduits for information. Some farmers look for simple solutions to the complex questions posed by soil fertility management, crop protection, or water use. If we can help transform these farmers into colearners who can contribute their expertise to the university educational process, we anticipate that they will soon become confident codevelopers of knowledge instead of passive receivers of recommendations from input suppliers. Moreover, they will become a valuable source of practical experience and ideas for our students. 
In the agroecology MSc program in Norway, we start the learning process on the farm. The farmer and others directly involved in the farming system have a wealth of practical experience that is potentially valuable to students. When we express confidence in this resource's importance and facilitate student interactions on the farm, the stakeholders can become valuable resource persons who can add value to the learning process. For this reason, our student teams work on farms directly with farmers, walk the fields, and discuss goals, crops, animals, and practices. They follow up with questions about how the whole system fits together, what the farmer sees as major constraints, and higher-order issues such as making the farm more resilient in uncertain weather and economic times. They ask about long-term issues such as succession in ownership planning. Together with farmers and mentored by instructors, student teams codevelop potential scenarios with farmers to help them engage in long-term planning. The same process is followed by the more complex issue of working with communities and their food systems to overcome current constraints and planning to achieve long-term goals. This is a colearning environment that has proven valuable to our agroecology students, as they learn observation, interview, interaction, and visioning skills together with stakeholders in the pursuit of creative options that will help them be successful in the future.

One key indicator of how farmers and food systems people value the interactions with student teams comes from more than two decades of course reflections about the stability of a core group of stakeholders in Norway. Some of the farmers have been willing to host student teams visiting their farms since the first PhD course, conducted in 1995. There have been some changes over the years, but in 2019 the four farms we visited for preliminary practice visits and interviews were the same farms and mostly the same farmers from 25 years ago. The farmers receive no compensation for volunteering their time and expertise and often comment that they benefit from the young energy and important questions raised by each new group of students. Some project farms have changed over the years. Community food system sites have changed as we have shifted focus from primarily rural farms to those in and near cities that sell to local consumers. Surprisingly, to us, for several years, some communities in Norway were so pleased with the student project work, especially the future visioning sessions, that they contributed monetary support for some of the housing of students in their communities. It helped that we had former students in key roles as county agricultural advisors in these places. We have been pleased by the consistent and positive reception our student teams get from these food system professionals who donate their time to the learning endeavor. We need to do a more thorough and formal evaluation of this program dimension to assess how farmers and other stakeholders view themselves as part of the transformation process.

\section{Institutional Transformation to Promote Coearning}

We often may blame the university structure, course requirements, or lack of time and resources as major constraints to transforming education on a larger scale. A more positive approach is to carefully assess the resources we do have - time, classrooms, fields, teaching funds, nearby stakeholders - and thoughtfully ask ourselves, "How do we use these available resources to the best advantage for student learning"? If we are convinced that colearning is one way to tap into these resources, including the expertise of diverse stakeholders in farming and food systems, then we can better mobilize and direct what is available. We can tap into the multiple talents of all the players, and their intellectual and material resources, to design a colearning situation that will be most relevant and effective in having students become change agents for a more resilient and sustainable future. 
This means major changes in how we view the university's role, the types of interactions and the contributions of different players, and how we can all best contribute to improving the local learning landscape.

In a recent workshop on visioning the future of organic agriculture teaching in 2025, a group of 16 educators gathered to explore what major challenges were expected in resources, climate, political situations, and other factors over the next decade. Then, we discussed what changes in materials and methods for teaching would be most helpful to students to meet these future challenges (Jabbour, Francis, Barberchick, \& Ullman, 2020). Our impression was that the educators were well informed about such pressing global issues and projections as climate change, resource scarcity, human population growth, pollution, and other key challenges. Jabour et al. (2020) reported several observations from the educator group related to transformative changes we will need in educational institutions to promote more participatory learning activities. Included are the authors' speculations on needed changes. The teacher group agreed that:

- There is a need for more practical, hands-on learning activities, skill-building, and finding funds for additional facilities or support

- We need more opportunities for face-toface structured learning with farmers on farms and resources for providing transportation options for individuals and classes to get to the field

- There is a need for relevant apprenticeships structured in learning, evaluation, reflection, and reporting that promote closer collaborations with farmers, industry groups, and nonprofit organizations

- Learning should be student-driven and include open-access lectures, thus redefin- ing how courses are designed and providing incentives for instructors to make these changes

- The innovative design of learning environments, flipped classrooms, and hybrid environments are needed and may be achieved by adjusting classrooms and computer systems to facilitate these learning venues

- Partnerships and interdisciplinary learning, coteaching, and colearning teams are essential and can be facilitated by modifying learning spaces to include round tables for groups and minimizing investments in lecture halls

- We should learn from mistakes, encourage acceptable risks, and create multiple avenues of engagement by fostering a climate of experimentation in learning and providing rewards for failure and success

- We should create cross-cultural competency and encourage more travel experiences outside this country by providing opportunities and facilitating travel programs and student exchanges

We were less impressed by our collective inability to envision viable needed changes in farming and food systems, and we observed a lack of innovative teaching methods to develop and implement them. We insisted on the importance of effective long-range visioning as a key competency for our students to develop. Yet these workshop results suggest that we have much to learn ourselves in terms of adequately thinking about the future and the changes we need to make, along with our institutions, in order to be effective learning catalysts. It was evident that there are more transformations needed for adequately improving the educational process and that more time should be invested in this essential endeavor. 


\section{General Discussion and Outreach with a Transformational Model}

After 20 years of implementing the agroecology MSc at NMBU, we have reflected on the successes and shortcomings of the program and explored how to evaluate its activities and learning processes, especially with respect to assessing outcomes to date and exploring what conditions made these possible. We first discuss several success indicators, move on to some challenges that continually recur, and finally, discuss our outreach with other universities and describe how they have adapted the above ideas into specific agroecology educational programs. Based on this commentary, we present a number of conclusions and potential changes for the future.

Since the beginning of the MSc program, there have been two key faculty teachers and one parttime visiting professor to provide continuity and innovation. We were joined by a postdoc who has been a faculty member for the past six years. The agroecology specialization and at least 20 new students per year represent over half of all new MSc students in the plant science department at NMBU. Instructor stability projects an image of sustainability to the administration and colleagues in the academy. We have been dedicated to this initiative for an extended time and have consistently found support from the university's administration at all levels. The program has further gained credibility in the university with its publication record that includes over 50 refereed journal articles, 15 book chapters, and numerous proceedings papers authored by team members and students. This record has also strengthened the image of agroecology at universities in Europe and the U.S., and the term and focus on 'agroecology in farming and food systems' has found its way into the titles of numerous books and a new journal, Agroecology and Sustainable Food Systems, published by Taylor and Francis in the U.K.
The most important outcomes are the students and graduates from the agroecology MSc. There has been consistent enrollment, starting with 12 in the first year and averaging 20 students from at least 10 countries each year for the past decade, and with nearly 300 people completing the degree over two decades. Students report that they have applied each of the core competencies to some degree in their projects and research. They reported this in the autumn course report in their final learning evaluations, and again after completing their thesis projects. They considered observation skills as especially important when launching research in environments new and unfamiliar to them, while participation and dialogue skills were found useful in their work with farmers and food system stakeholders. The social science methods used to gather information about systems have been considered particularly valuable. The reflection skills that few had used before the autumn agroecology class were also considered important, and students reported using visioning in both village meetings and organizational activities. In recognition of several educational innovations, the program was awarded the NOVA Prize from the AGROASIS Agroecology Network in the Nordic Region in 2007; the All-University Excellence in Education Award from the Norwegian University of Life Sciences in 2011; and the National Teaching Quality Prize from NOKUT (Norwegian Education Quality Program) in 2016. Some of these have included additional operating funds earmarked for hiring a postdoc, supporting student travel, or financing other student-related educational needs. Details on the program are on the NMBU website at https://www.nmbu.no/course/pae302.

There are several ongoing challenges for the continued success of the program in Norway, and these include:

- A lack of recognition of the degree in agroecology by some governmental agencies, as this is a relatively new field and the 
specific qualifications for agroecology are not on their lists of desired degrees

- Continued discussions about the definition of agroecology and whether this includes practices, science, or social movements, which complicates communication and the establishment of an agreed-upon identity

- Limited acceptance of agroecology as a legitimate field of study, compared to well-known disciplines such as crops, soils, genetics, entomology, and economics

- Scarce funding for student thesis research in the university's tight economic climate, which has been overcome in part by collaborating on projects with other departments, and with support from nonprofit groups

- Ongoing concerns among agroecologists about whether this transdisciplinary field should take its place among other disciplines in the academy or continue to identify itself as a unique, separate, and transdisciplinary area of study and research

One compelling indicator of this program's value is our successful role in helping to establish similar agroecology certificate or degree programs in Sweden, France, Italy, India, Ethiopia, Uganda, and Chile. On the Alnarp Campus of the Swedish Agricultural University, an MSc degree program was established a decade ago modeled on Norway's program. Students in Sweden and Norway have worked together on projects, attended each other's educational events, and together developed an Agroecology Student Handbook in the fall of 2019. At ISARA (Agro School for Life) in Lyon, France, a two-year MSc program has been running for more than a decade, and now has double degree programs with three universities in France and six in other countries. Mekelle University in Ethiopia and Uganda Martyrs University in Kampala established MSc degree programs, primarily for in-service advancement of extension advisors, with support from SIDA, the Swedish International Assistance Program. In India, two programs have been established. The first was a six-month certificate program at Calcutta University in the Centre for Agroecology and Pollination Studies. More recently, a certificate program was established in Kerala in their new Centre for Agroecology and Public Health, and the organizers are awaiting approval of a twoyear MSc program. Negotiations are underway to help begin a similar degree program in Sri Lanka, and an MSc program will begin in 2021 at the University of Chile in Santiago.

\section{Conclusions \& Future Directions}

This demonstrated success of the agroecology MSc degree program in Norway, as well as other academic initiatives in several countries, is indicative of the growth of agroecology as a field of study and demonstrates growing support for this type of holistic research and education. Participatory learning is at the heart of the educational activities, and the methods adopted and evaluated in Norway have proven valuable in other countries. We see the approach as part of a 'living curriculum' that can evolve and adapt as we gain more experience in Norway and elsewhere. The model's application is unique for each university, with program adjustments needed due to differing agroecosystems, as well as cultural and educational differences. Similar to the idea that farming systems are unique to each place and its terroir, we think the same is true of educational programs. As we work together with students in colearning environments to better prepare all of us for handling complexity and change, we consider learning goals to be universal in order to link theory to real life, to communicate and facili- 
tate in groups, and to develop a capacity for lifelong learning.

Central to our success has been frequent communication through team meetings, the immediacy we establish in teacher/student/stakeholder learner communities, and experimentation with new ideas. We also not only get student feedback but seriously respond to student ideas. Continuity has been maintained through adequate administrative support and the dedication of the instructors, with high degrees of trust having been established among the core instructors. Our growing research profile includes urban and peri-urban food production with attention to whole food systems that will support our educational activities. We need to pay attention to the importance of an educational succession plan since key program leaders' potential retirements are imminent over the next decade. The educational ideas for colearning in agroecology are highly appropriate in this time of international uncertainty due to the current global COVID-19 pandemic; the methods developed in the program provide skills and tools to help adapt to new realities. It is exciting to be on the cutting edge of change.

\section{Acknowledgements}

This manuscript summarises the authors' intended contribution at the Workshop on Challenges for Agroecology Development for the Building of Sustainable Agri-Food Systems (CRP), which was due to take place at the Faculty of Agricultural Sciences, University of Chile, Santiago de Chile, on 11-13 November 2019, and which was sponsored by the OECD Co-operative Research Programme: Biological Resource Management for Sustainable Agricultural Systems. Although due to the circumstances the workshop did not take place as a physical meeting and contributions intended to be supported by the OECD CRP are published in this Thematic Issue.

\section{Disclaimer}

The opinions expressed and arguments employed in this manuscript are the sole responsibility of the authors and do not necessarily reflect those of the OECD or of the governments of its Member countries.

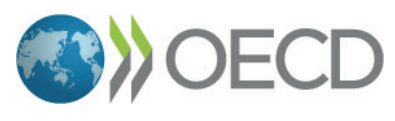

\section{Resumen}

C.A. Francis, A.M. Nicolaysen, G. Lieblein, y T.A. Breland. 2020. Innovaciones transformativas en el codiseño de educacion en agroecologia. Int. J. Agric. Nat. Resour. 280-294. La evolución de educación en agroecología ha seguido una transformación rapida y profunda, en parte porque es una especialidad de estudios de sistemas holísticas sin una larga história academica con mucha tradición formal. La definición de agroecología ha seguido varias ampliaciones en pocos años, del 'matrimonio de la agricultura con la ecología', a una serie de areas de conocimiento y aplicación como 'ciencia - practicas - movimiento', hasta lo mas amplio, 'la ecología de sistemas de alimentos'. En contraste con los cursos tradicionales, que empiezan con la historia y los antecedentes en la academia, empezamos nuestras exploraciones de la agroecología aprovechando el concepto de fenomenología, para establecer los raices del estudio en las experiencias de agricultores y otras personas involucradas en el sistema de alimentos. En la aplicación del concepto, facilitamos una estrecha colaboración entre estudiantes, profesores, agricultores, y otros en el sistema de alimentación, para asegurar 
que todos reconocen una posesión del concepto y los resultados de la educación. Además, en el diseño de cursos y las actividades, buscamos las ideas y participatión de estudiantes como miembros del equipo, explorando juntos en el paisaje de aprender la importancia y detalles que contribuyen a sistemas sostentables en el largo futuro. Participamos juntos en una inmersión completa en la búsqueda del significado y las prácticas de agroecología, y juntos podemos avanzar el proceso de cambio profundo en el sistema de producción y alimentación. Intentamos a desarrollar cinco capacidades claves para investigar los sistemas en el campo: la observación, el diálogo, la participación, la reflexión, y el proceso de alcanzar una visión clara del futuro. El proceso requiere transformación del papel de todos los actores en la educación, asi como atención a las facilidades y cambios en administración. Una meta es de empoderar cada estudiante para tomar una responsabilidad amplia, llamado apropiadamente 'el co-diseño de educación’.

Palabras clave: Co-aprendizaje, fenomenología, participación del administrador, participación de los estudiantes, participación de los interesados.

\section{References}

Carlisle, L., Montenegro de Wit, M., DeLonge, M. S., Iles, A., Calo, A., Getz, C., Ory, J., MundenDixon, K., Galt, R., Melone, B., Knox, R., \& Press, R. (2019). Transitioning to sustainable agriculture requires growing and sustaining an ecologically skilled workforce. Frontiers in Sustain. Food Sys. 3:Article 96. doi: https://doi. org/10.3389/fsufs.2019.00096.

Conroy, A. B., Overson, C. E., \& Erickson, P. S. (2019). Alumni perspectives of using a flipped classroom and experiential learning at a university dairy farm. NACTA J. 63(2): 299-306.

Estepp, C. M., \& Roberts, T. G. (2015). Teacher immediacy and professor/student rapport as predictors of motivation and engagement. NACTA J. 59(2):155-163.

Field, D. J., Yates, D., Koppi, A. J., McBratney, A. B., \& Jarratt, L. (2017). Framing a modern context of soil science learning and teaching. Geoderma 289:117-123. doi: https://doi.org/10.1016/j.geoderma.2016.11.034

Francis, C., King, J., Lieblein, G., Breland, T. A., Salomonsson, L., Sriskandarajah, N., Porter, P., \& Wiedenhoeft, M. (2009). Open-ended cases in agroecology: farming and food systems in the
Nordic Region and the U.S. Midwest. J. Agric. Educ. Extension 15 (4):385-400. doi: https://doi. org/10.1080/13892240903309645

Francis, C., Morse, S., Lieblein, G., \& Breland, T. A. (2011). Building a social learning community. Teaching Tips. NACTA J. 55(3):99-100.

Francis, C., \& Steiro, Å. (2018). Participatory learning workshop: email survey results summarized and workshop exercise. In Proc. ENOAT Workshop, Kuchtova, P., Rembiałkowska, E., \& Francis, C., editors. Prague, Czech Republic, September 26-27.

Francis, C.A., Østergaard, E., Nicolaysen, A.M., Lieblein, G., Breland, T.A., \& Morse, S. (2015). Learning agroecology through involvement and reflection. In V.E. Méndezet al. (Eds.), Agroecology: A Transdisciplinary, Participatory and Action-oriented Approach. (pp. 73-98).CRC Press, Taylor \& Francis Group Boca Raton, Florida.

Freire, P. (1968). Pedagogy of the oppressed. [originally Pedagogia do Oprimido, in Portuguese]. Verlag Herder, Freiburg im Breisgau, Germany. (50th Anniversary Edition, 2018).

Hartemink, A.E., Balk, M.R., Chen, Z.S., Drohan, P., Field, D.J., Krasilnikov, P., Lowe, D.J., Rabenhorst, M., van Rees, K., Schad, P., Schipper, L.A., Sonneveld, M., \& Walter, C. (2014). 
The joy of teaching soil science. Geoderma 217-218:1-9. doi: https://doi.org/10.1016/j.geoderma.2013.10.016

Jabbour, R., Francis, C., Barberchick, M., \& Ullman, K.S. (2020). Organic agriculture teaching and learning in 2025: a futuring workshop to transform the learning landscape. NACTA $J$. 64:183-187.

Jordan, N.R., Andow, D.A., \& Mercer, K.L. (2005). New concepts in agroecology: a_service-learning course. J. Natural Res. Life Sci. Education 34(1):83-89. doi: https://doi.org/10.2134/jnrlse.2005.0083.

Kainer, K.A., Binnqüist, C.L., Dain, J.L., Contreras Jaimes, B., Negreros Castillo, P., Gonzalez Basulto, R., \& Melchor Contreras, F. (2019). Leading by listening, learning by doing: modeling democratic approaches to conservation leadership in graduate education. J. Environ. Studies and Sci. 9(2):206-217. doi: https://doi. org/10.1007/s13412-019-00542-3.

Lieblein, G., Breland, T.A., Francis, C., \& Østergaard, E. (2012). Agroecology education: actionoriented learning and research. J. Agric. Education \& Extension. 18(1):27-40. doi: https://doi.or g/10.1080/1389224X.2012.638781

Lieblein, G., Francis, C., Barth-Eide, W., Torjusen, H., Solberg, S., Salomonsson, L., Lund, V., Ekblad, G., Persson, P., Helenius, J., Loiva, M., Seppänen, L., Kahiluoto, H., Porter, J., Olsen, H., Sriskandarajah, N., Mikk, M. \& Flora, C. (2000). Future education in ecological agriculture and food systems: a student-faculty evaluation and planning process. J. Sustain. Agric. 16(4):49-69. doi: https://doi.org/10.1300/J064v16n04_06
Lieblein, G., Østergaard, E., \& Francis, C. (2004). Becoming an agroecologist through action education. Intl. J. Agricultural Sustainability (U.K.) 2(3):147-153. doi: https://doi.org/10.1080/1473 5903.2004.968457

MacDonald, J.M., Hoppe, R.A., \& Newton, D. (2018). Three decades of consolidation in U.S. agriculture, EIB-189. U.S. Department of Agriculture, Economic Research Service, Washington, D.C., U.SA. doi: https://doi.org/10.22004/ ag.econ. 276247

McCubbins, O.P., Paulsen, T. H. \& Anderson, R. (2019). Conceptualizing the integration of teambased learning into a capstone farm management course: advice from Larry Michaelsen. NACTA J. 63(2):311-318.

Mendez, V.E., Bacon, C.M., Cohen, R., \& Gliessman, S.R. (editors). (2015). Agroecology: a transdisciplinary, participatory and action-oriented approach. CRC Press, Taylor \& Francis Group, Boca Raton, Florida.

Østergaard, E., Lieblein, G., Breland, T.A., \& Francis, C. (2010). Students learning agroecology: phenomenon-based education for responsible action. J. Agric. Education Extension (Wageningen). 16(1):23-37. doi: https://doi. org/10.1080/13892240903533053

Wezel, A., Casagrande, M., Celette, F., Vian, J.F., Ferrer, A., \& Peigné, J. (2014). Agroecological practices for sustainable agriculture. A review. Agron. Sustain. Dev. 34:1-20. doi: https://doi. org/10.1007/s13593-013-0180-7

Wezel, A., \& Francis, C. (2014). Multi-language challenges in international agroecology courses. NACTA J. 58(2):177-179. 